\title{
DEFINISI DIRI DAN DEFINISI SITUASI REMAJA DALAM PENJAJAKAN KARIER
}

\author{
Oleh: Fitriana, ${ }^{1}$ Andi Mappiare-AT, ${ }^{2}$ Muslihati $^{3}$ \\ ${ }^{1}$ Institut Agama Islam Muhammadiyah Sinjai, \\ Jl. Sultan Hasanuddin, No. 20 Balangnipa, Sinjai \\ E-Mail: fitrimyrmica0789@gmail.com, TIp.:08114616789 \\ ${ }^{2}$ Universitas Negeri Malang \\ ${ }^{3}$ Universitas Negeri Malang
}

\begin{abstract}
Abstrak
Kajian ini didasarkan pada pentingnya definisi diri dan definisi situasi dalam kehidupan manusia. Salah satunya dalam hal perjalaan karir, misalnya sebelum memutuskan untuk menjadi apa, mau kerja apa, siapa sayadan pekerjaan apa yang cocok untuk saya selalu diawali oleh pertimbangan yang ditentukan sendiri oleh pelaku karir yang disebut sebagai definisi diri. Begitu juga dalam mendefinisikan situasi, setiap orang melalui tahap pengujian dan pertimbangan dalam menghadapi setiap situasi sebelum mengambil tindakan yang disebut sebagai definisi situasi.Pada intinya definisi diri dan definisi situasi merupakan hal konkret yang menjadi pertimbangan sendiri ketika orang dihadapkan pada situasi-situsi pilihan untuk berbuat atau tidak. Hal itu tentu saja berperan dalam hal pengambilan keputusan, salah satunya dalam pilihan-pilihan pekerjaan. Fokus dalam kajian ini adalah mengetahui pola definisi diri dan definisi situasi yang berperan dalam membentuk konstruksi pemikiran subjek tentang dunia karier.Adapun subjek dalam penelitian ini adalah subjek tunggal dimana data dianalisis menggunakan unit analisis individual.
\end{abstract}

\section{Kata Kunci: Definisi Diri, Definisi Situasi, Penjajakan Karier}

\section{PENDAHULUAN}

$\mathrm{P}$ ada umumnya orang dewasa sibuk mengawali harinya dengan urusan mencari nafkah hidup. Tidak sedikit juga orang masih dalam proses mencari pekerjaan, melamar kemana mana untuk memperoleh pekerjaan tetap. Juga, ada orang yang masih senang dengan kehidupannya yang tanpa kerja meskipun telah berada dalam usia yang tidak muda lagi. Fenomena-fenomena di dunia kerja seperti ini memberikan keberagaman pola pikir orang dalam menjalani dunia kerja.Tidak bisa dipungkiri bahwa pemahaman yang mencakup nilai-nilai dan atau makna kerja seseorang itu sangat dipengaruhi oleh sesuatu yang kompleks, sehingga mereka menciptakan pola hidup sendiri yang berdampak pada budaya kerja mereka. Apakah itu pengaruh lingkungan, pola asuh, keluarga, dan latar belakang sosial ekonomi serta etnis budaya orang itu sendiri.

Dalam perjalanan karir khususnya dalam merumuskan orientasi karir, orang memiliki pertimbangan yang dipengaruhi oleh budaya, pola pikir, begitu pula dengan situasi yang akan berpengaruh terhadap pilihan karier orang yang bersangkutan. Dimana sebelum memutuskan untuk menjadi apa, mau kerja apa, siapa saya dan pekerjaan apa yang cocok untuk saya selalu diawali oleh proses evaluasi yang ditentukan sendiri oleh pelaku karir. Disitulah proses seseorang mendefinisikan dirinya. 
Proses pilihan karier terjadi di sepanjang hidup manusia, artinya suatu ketika dalam perjalanan karir seseorang, dimungkinkan akan terjadi perubahan paradigma berpikir tentang dunia kerja. Hal ini kemudian bisa dimaknai bahwa pemilihan karier seseorang itu tidak terjadi sekali saja dalam hidup manusia. Seseorang bisa saja menentukan pilihan kariernya berdasarkan minat, bakat dan nilai yang akan diyakini, tetapi banyak faktor yang menyebabkan cita-cita seseorang akhirnya tidak bisa terwujud. Salah satunya adalah situasi yang dihadapi sebelum melakukan pengambilan keputusan dalam pekerjaan.

Banyak orang terjebak dalam proses pencarian pekerjaan karena sebuah kontroversi antara diri dan situasi untuk mencocokkan karakteristik pribadi dan pekerjaan yang ditawarkan berhubungan dengan kepuasan kerja, stabilitas, dan penghargaan yang diperoleh. Begitu juga dengan takdir dan keberuntungan dalam bekerja terkadang menjadi faktor penentu kesuksesan seseorang. Super (1983: 556) menjelaskan bahwa pilihan karir adalah proses mencocokkan (matching). Pengalaman hidup yang diperoleh setiap orang akan mempengaruhi pola pikir dan pola tindak yang tentunya berakar dari interpretasi subjektifnya. Dalam memahami konteks situasi yang dialami oleh subjek, Thomas menjelaskan bahwa dalam mengawali setiap tindakan perilaku yang ditentukan sendiri, selalu ada tahap pengujian dan pertimbangan yang dapat kita sebut sebagai definisi situasi (Thomas, 1986: 34). Sepadan yang diungkapakan oleh Egloff (2015), bahwa konsep definisi situasi mengacu pada interaktif proses mental untuk menentukan makna dan perilaku selanjutnya oleh dan untuk individu dan kelompok yang diberikan situasi.

Di kehidupan sehari-hari kita akan menemukan manusia-manusia yang memiliki pandangan hidup yang berbeda. Semuanya merujuk pada satu keprihatian utama, yaitu tuntutan akan pengendalian uang, waktu, ruang hidup, dan tubuh milik orang itu sendiri. Dengan kata lain, orang punya hak untuk mengembangkan perspektifnya sendiri atas kehidupan. Dalam memahami hal tersebut, ada tahap dimana kita harus mengerti bagaimana konstruksi pemikiran seseorang, cara mendefinisikan diri serta situasi-suatusi yang dihadapi selama hidupnya sebagai langkah awal untuk lebih memahami manusia yang dihadapi.

Kaitannya dengan dunia Bimbingan Konseling, menurut Robak (2001), salah satu proses penting dalam proses konseling dan psikoterapi adalah narasi dari sebuah cerita pengalaman hidup. Beberapa pendekatan fokus pada hal-hal yang mendasari orang untuk mendefinisikan dirinya serta bagaimana mereka mengobservasi perilaku mereka sendiri di dalam variasi situasi yang dihadapi serta atribusi yang dibuat. Sebagian besar dari kita lebih suka mengaitkan penyebab perilaku orang lain dengan ciri kepribadian atau faktor internal, bukan faktor situasional. Kita cenderung berpikir bahwa tindakan orang lain disebabkan oleh sesuatu di dalam diri, bukan karena disebabkan oleh circumtances, atau faktor situasional eksternal. Konselor dalam memahami individu sebagai konseli, definisi diri dan definisi situasi merupakan hal yang sangat penting sebagai bagian dari teknik eksplorasi dan atau pada tahap pengungkapan diri dalam konseling. 
Fokus dalam kajian ini adalah mengetahui pola definisi diri dan definisi situasi yang berperan dalam membentuk konstruksi pemikiran subjek tentang dunia karier. Serta, bagaimana implikasi konseling berperan dalam menghadapi subjek terteliti. Dalam hal ini, aspek definisi diri dan definisi situasi itu diperoleh dari deskripsi fluktuasi pengalaman hidup yang dilalui subjek pada masa lalu, sekarang serta gambaran masa depan yang dicita-citakan.

Adapun tujuan dari penelitian ini diharapkan memperkaya konsepsi pemikiran dan perilaku subjek. Istilah definisi diri adalah salah satu bagian dari "self" yang masih jarang diungkap dalam penelitian. Oleh karena itu diharapkan penelitian ini bisa menjadi referensi untuk kalangan mahasiswa dan peneliti lainnya. Definisi situasi merupakan teori sosiologi, dikaitkan dengan Bimbingan Konseling yang multidisipliner ilmu, diharapkan istilah ini mampu menjadi pengetahuan baru yang menjadi pertimbangan dalam menganalisis situasi-situasi hidup konseli yang tidak lain merupakan bagian dari pelaksanaan konseling.

\section{METODE}

Penelitian ini menggunakan metode penelitian kualitatif yang mengungkap gejala secara holistik-kontekstual melalui pengumpulan data dari latar alami dengan memanfaatkan diri peneliti sebagai instrumen kunci. Penelitian ini menggunakan rancangan kualitatif dengan pendekatan fenomenologi, yaitu peneliti berusaha untuk masuk ke dalam dunia konseptual subjek yang diteliti, sehingga peneliti mengerti apa dan bagaimana pandangan/pemikiran subjek tentang fenomenafenomena yang dihadapi. Peneliti kualitatif ini menggunakan metode Fenomenologi Empiris yang melibatan kembali ke pengalaman yang "sungguh-sungguh dipahami orang atau subjek" (MappiareAT., 2013: 80). Metode ini membantu peneliti memasuki sudut pandang orang lain, dan berupaya memahami mengapa mereka demikian. Metode fenomenologi ini tidak hanya melihat perspektif para partisipan saja, tetapi fenomenologi juga berusaha memahami kerangka yang telah dikembangkan oleh masing-masing individu, dari waktu ke waktu, hingga membentuk tanggapan mereka terhadap peristiwa dan pengalaman dalam kehidupannya.

Penelitian ini menggunakan subjek tunggal dimana analisis data yang digunakan adalah unit analisis individu. Adapun analisis data dilakukan melalui tiga tahap, yaitu reduksi fenomenal, reduksi euditik, dan reduksi transendental. Kehadiran dan keterlibatan peneliti di lapangan adalah untuk menemukan makna dan tafsiran dari subjek yang tidak bisa digantikan dengan alat lain (non human) dalam hal ini peneliti memanfaatkan dirinya sebagai instrumen utama. Dalam penelitian ini, peneliti bertindak sebagai pengumpul data dan sebagai instrumen aktif. Peneliti mengambil lokasi di kediamannya sendiri. Peneliti mengambil lokasi tersebut karena subjek menghabiskan waktunya lebih banyak (selain kerja) di kediaman peneliti. Sehingga, interaksi antara subjek dan peneliti bisa dikatakan sangat efektif. Pengumpulan data dilakukan dengan beberapa teknik yaitu dengan life story, wawancara mendalam, observasi partisipatif, dan media sosial. 


\section{HASIL DAN PEMBAHASAN}

\section{Definisi Diri}

Berdasarkan hasil analisis, terdapat beberapa aspek definisi diri yang dimiliki oleh subjek sebagai pemuda yang memiliki kemampuan "survive" sebagai pemburu kerja. 1) sederhana dan rendah diri, 2) kemandirian, 3) pekerja keras, 4) pemberani, 5) malu jika tidak bekerja, 6) seorang petualang, 7) terampil, dan 8) motivasi yang besar, 9) petarung, 10) Nomaden (pekerjaan tidak tetap), dan 11) kemampuan beradaptasi, yang kemudian digambarkan dalam bentuk pola fluktuasi definisi diri.

Adapun aspek-aspek tersebut dikelompokkan menjadi dua bagian berdasarkan fluktuasi yang terjadi dalam diri subjek. Pertama, definisi diri superior dan kedua definisi diri inferior. Pengelompokan ini berdasarkan pada aspek yang menonjol yang ada pada diri subjek yang memiliki pengaruh yang dominan terhadap performa kerjanya disebut sebagai definisi diri superior, dan juga aspek yang menjadi pendukung/ turunan dari aspek dominan yang disebut definisi inferior.

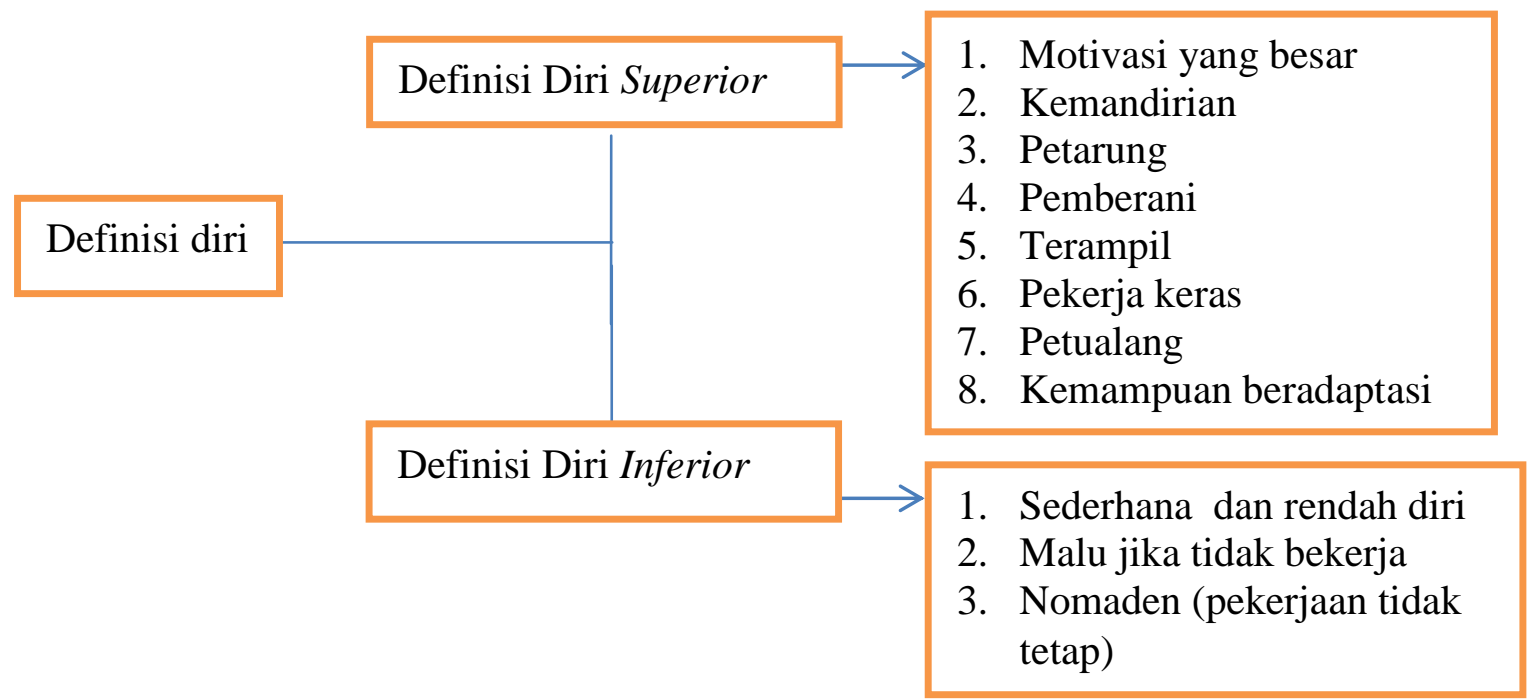

Gambar 3.3.1 Pengelompokan Aspek Definisi Diri.

Fluktuasi definisi diri yang dimaksud dalam hal ini adalah ketika terjadi proses naik-turun definisi diri (kapan definsi superior muncul, atau sebaliknya definisi inferior muncul). Hal ini bergantung pada konteks waktu atau situasi yang dialami oleh subjek. Pada dasarnya subjek selalu mendefinisikan dirinya dalam kategori superior, akan tetapi munculnya kategori inferior ketika subjek merasa orang tuanya tidak bangga dengan keputusannya untuk menjadi pekerja yang nomaden. Hal tersebut mempengaruhi setiap keputusan-keputusan subjek dalam membangun kepercayaan dirinya, sehingga terkadang merasa bahwa ia mempermalukan dan mengecewakan orang tuannya.

Pada saat seseorang mencoba mendefinisikan dirinya sendiri dapat dikatakan bahwa terjadi hubungan antara diri dan situasi yang selalu berubah-ubah. Karena itu, saat seseorang berpikir tentang definisi dirinya, subjek terkadang menjadi sadar akan bagaimana orang lain mewakili diri mereka sendiri. Proses ini dapat bervariasi sesuai dengan konteks yang berbeda, pengaruh sosial dan budaya sesuai dengan tujuan dan sasaran yang berbeda. Misalnya, ketika mencoba mencari pekerjaan (Patton, 
2005) dari perspektif konstruktivis, pengembangan kompetensi karir melibatkan lebih dari hanya aktivitas kognitif dalam menyelaraskan diri, informasi pekerjaan dan kontekstual informasi. Tapi terjadi pengolahan informasi yang sangat penting bagi konstruksi individu dan integrasi pengetahuan dan keterampilan yang relevan dengan dirinya. Kisah karir subjek adalah kumpulan gambaran dari cara individu melihat dirinya di dunia, sedangkan aspek informasi diri (mis:minat, kemampuan) dan dunia kerja merupakan isi ceritanya sehingga konstruksi individu dan posisi subjek di dalam cerita (narasi individu tentang diri) memberikan keunikan tersendiri bagi masing-masing individu. Hal itulah kemudian membentuk pemahaman individu yang berperan proses pembelajaran.

Melihat fenomena kerja manusia di zaman postmodern, kenyataan menunjukkan bahwa orangorang yang memiliki perbedaan latar belakang budaya berbeda dalam hal mengkonseptualisasikan dan menikmati pekerjaan. Melihat kisah hidup subjek, bisa dikatakan bahwa telah ada perkembangan historis yang mengakibatkan dia kehilangan jaringan dukungan tradisionalnya (keluarga) dan harus mengandalkan dirinya sendiri dan nasibnya sendiri dengan semua resiko, peluang dan kontradiksinya sehingga subjek mengembangkan cara-cara hidup yang cenderung terindividualisasi.

Demi kelangsungan hidup ekonomi, subjek terpaksa membuat dirinya sebagai pusat rencana kehidupan dan perilakunya sendiri. Sehingga pada akhirnya menghasilkan sebuah definisi tentang makna kerja, sejauh mana dirinya, bagaimana dia menemukan identitas dirinya, dan bagaimana dia tetap bertahan dalam menghadapi situasi pengalaman yang berbeda.

Ada kecemasan tersendiri bagi diri bagi subjek ketika belum bisa menjawab pertanyaanpertanyaan umum dari orang-orang sekitarnya. Erich Fromm menyebutnya alienasi (2004: 76), sebuah konsep dimana pribadi yang teralienasi akan merasa minder ketika subjek menilai dirinya tidak berjalan pada rel yang umum. Karena pemahaman akan nilai didasarkan pada persetujuan dari luar sebagai hadiah bagi konfomitasnya, dengan sendirinya subjek merasa jati dirinya dan harga dirinya terancam dengan berbagai perasaan, pikiran dan tindakan yang dinilai orang lain sebagai menyimpang. Oleh karena itu subjek terus-menerus dilanda ketakutan lantaran ketidaksetujuan pihak lain. Akibatnya, dia semakin berusaha keras menyesuaikan diri dengan arus umum, agar disetujui dan diakui bahwa agar sukses. Di sini, bukan suara hatinya yang memperkuat dan memberi rasa aman, melainkan perasaan takut kehilangan pegangan dengan "mentalitas rombongan".

Menurut Robak (2001), narasi tentang diri merupakan kunci pokok dalam proses psikoterapi. Beberapa pendekatan terapi didasarkan pada pendekatan konstruktivisme, misalnya dalam menekankan klien untuk menciptakan realitas mereka sendiri, membangun kisah hidup mereka serta menemukan makna dari perjalanan hidup mereka. Pendekatan semacam itu berfokus pada proses definisi diri sebagai dasar utama. Meskipun pada pelaksanaannya, pengungkapan definisi diri tidak mengungkap secara keseluruhan atau menggambarkan karakteristik subjek secara tepat akan tetapi hal tesebut berguna untuk mendapatkan informasi tentang diri subjek yang dihadapi secara singkat dan efektif.

\section{Definisi Situasi}


Adapun aspek yang ditemukan dalam perjalanan hidup subjek adalah sebagai berikut: 1) pekerjaan adalah tempat belajar, 2) pekerjaan adalah tempat aktualisasi diri, 3) pekerjaan adalah wadah evaluasi diri, 4) pekerjaan yang baik adalah yang bebas, 5) dukungan orang tua - "tidak sejalan", 6) pekerjaan adalah jalan rejeki, 7) bekerja dibawah tekanan mengurangi performa kerja kemudian digambarkan dalam bentuk pola fluktuasi definisi situasi yang berperan dalam keputusankeputusan kerja subjek

Seperti halnya kategori definisi diri, definisi situasi ini di kelompokkan menjadi dua bagian yaitu pertama definisi situasi sebagai enabling factor dan definisi situasi sebagai contraining factor. Definisi situasi sebagai enabling factor adalah situasi kerja yang membuat subjek merasa ada faktorfaktor mendukung dan bermanfaat bagi perjalanan kariernya. Sedangkan definisi situasi sebagai contraining factor adalah situasi dimana subjek melihat bahwa situasi kerja yang ditemui belum sesuai dengan ekspektasi yang diimpikan disertai dengan ditemukannya faktor-faktor penghambat dalam mencapai tujuan dan impiannya.

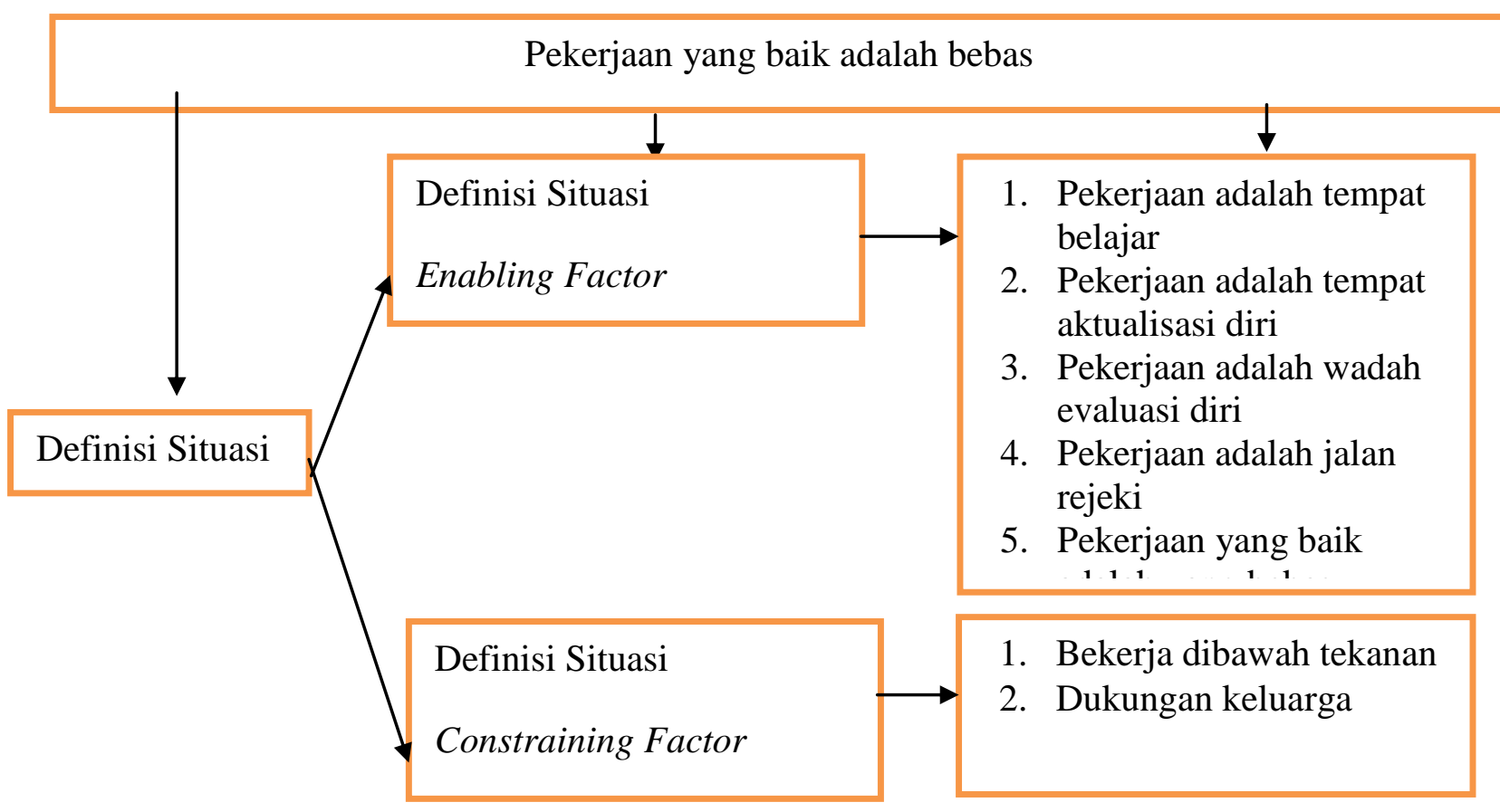

Gambar 3.3.2 Pengelompokan Aspek Defini Situasi

Mendefinisikan situasi dalam hal ini dunia kerja seseorang tidak lepas dari bagaimana subjek mendefinisikan dirinya. Ketika subjek melihat pekerjaan itu sebagai sebuah tempat belajar, disitulah subjek menemukan tantangan, rintangan, mendapatkan keterampilan baru, serta motivasi yang tinggi itu secara otomatis terbentuk. Cita-cita untuk membentuk sebuah pekerjaan yang bebas adalah tujuan hidup subjek. Hal itu yang menyebabkan ia sampai sekarang belum bisa menekuni satu jenis pekerjaan. Hal itu disebabkan karena tujuannya yang masih belum tercapai. Subjek belum menemukan pekerjaan yang diidamkan selama ini. Namun ketikasubjek merasa bahwa ia tidak mendapatkan dukungan keluarga, ia merasa menjadi penghalang dan pesimis. Akan tetapi dengan modal keyakinan 
dan motivasi yang lebih (definisi diri superiornya muncul), ia mampu menekan hal negatif tersebut menjadi sebuah hal positif. Fluktuasi definisi situasi yang terjadi dalam diri subjek merupakan efek yang terjadi akibat subjek belum bisa untuk menekuni satu jenis pekerjaan. Situasi kerja yang bebas meskipun telah menjadi cita-citanya, juga menjadi sebuah kendala bagi perjalanan karirnya. Subjek belum bisa dikatkan sebagai orang yang konsisten sebagai pekerja yang professional.

Bisa dikatakan bahwa akar dari problema kehidupan yang dialami oleh subjek adalah keinginan untuk bebas. Bebas dalam keterikatan, ada usaha untuk menjadi diri sendiri, tanpa interfensi orang lain. "Bekerja tanpa tekanan" tapi "belum bisa mendapatkan pekerjaan yang bebas". Sebuah bentuk tafsiran pribadi dalam memaknai kerja. Sehingga pada dasarnya "bekerja" adalah manifestasi dari ke"diri"an sebagai proses berkelanjutan untuk meningkatkan pergolakan antara "diri" dan "situasi". Banyak orang terjebak dalam proses pencarian pekerjaan karena sebuah konstroversi antara diri dan situasi untuk mencocokkan karakteristik pribadi dan pekerjaan yang ditawarkan berhubungan dengan kepuasan kerja, stabilitas, dan penghargaan.

Puncak dari definisi situasi subjek adalah pencarian pekerjaan yang membebaskan. Bagi Marx, pekerjaan seseorang benar-benar merupakan "pekerjaannya sendiri" hanya ketika itu merupakan aktifitas yang bebas dan diarahkan oleh diri sendiri serta bersidat spontan. Seorang makhluk tidak menganggap dirinya sebagai orang yang bebas kecuali dia adalah tuannya sendiri, penciptaan atas sesuatu itu bersumber dari dirinya. Seseorang dikatakan memiliki pekerjaannya sendiri jika hal tersebut merefleksikan kepentingannya, merealisasikan personalitasnya, dan didorong oleh kebutuhannya sendiri untuk membangun, menciptakan atu melakukan sesuatu yang merupakan pilihannya sendiri.

Dalam hal ini pembagian dua aspek dari definisi situasi ini, yaitu enabling factor (faktor pendukung) dan constraining factor (faktor penghambat) juga senada dengan istilah yang di ungkapkan oleh Rotter yaitu tentang Locus Of Control yang juga dikaitakan dengan teorinya Weinner tentang penentu keberhasilan seseorang. Subjek memiliki inisiatif untuk maju, dia memiliki semangat dan keyakinan untuk sukses. Weiner (1986: 37) berpendapat bahwa ada 4 komponen yang cukup untuk memungkinkan individu untuk menjelaskan penentu perasaan keberhasilan atau kegagalan seseorang yaitu, kemampuan, usaha, kesulitan tugas, dan keberuntungan yang dibagi menjadi dua dimensi yaitu stabilitas dan Lokus of Control. Merupakan teori yang dikembangkan oleh Rotter berkaitan dengan sumber pengendalian, di mana menurut teori ini seorang individu percaya bahwa hasil dari suatu kejadian dalam hidup mereka adalah pengendalian diri sendiri (Hamilton \& Harper,1994).

Menurut Super (1985: 7), meskipun ada periode pengangguran dan meskipun ada perubahan radikal dalam pekerjaan, orang yang memiliki pengalaman perubahan ini tetap orang yang sama. Pemilihan karir adalah sebagai bentuk perkembangan, karena didasarkan bahwa kerja adalah suatu 
wujud konsep diri.Dalam artian orang memiliki konsep diri dan dia berusaha menerapkan konsep diri itu dengan memilih pekerjaan. Pandangan umum masyarakat sebagai konsekuensi sosial yang akan diperoleh oleh subjek adalah dia diklaim sebagai orang yang tidak memiliki tujuan hidup jelas. Masyarakat bugis akan menyebutnya sebagai to lao sala (disorientasi karir). Akan tetapi lebih dari itu, subjek memiliki misi hidup yang jauh lebih bermakna yang tersirat mengenai perjuangan hidup. Ada upaya untuk mencari pengetahuan, bertarung melawan nasib serta bagaimana ia menempatkan kuasa Tuhan dengan menebak takdir yang nantinya akan ia peroleh.

Pemilihan karir adalah sebagai bentuk perkembangan, karena didasarkan bahwa kerja adalah suatu wujud konsep diri. Dalam artian orang memiliki konsep diri dan dia berusaha menerapkan konsep diri itu dengan memilih pekerjaan. Salah satu dimensi baru dari konseling vokasional dan karir adalah pengakuan akan kontinuitas sampai dengan diskontinuitas dalam karir. Pendapat Super tampak selaras dengan pendapat Herr dan Cramer (1984) yang menegaskan bahwa bagi setiap orang, karier itu unik dan diciptakan oleh kondisi: apakah seseorang memilih atau tidak memilih. Karier itu dinamis dan membentang di seluruh kehidupan.Karier tidak hanya menyangkut okupasi saja, tetapi juga mencakup kegiatan kehidupan praokupasi dan pasca vokasional. Sebagian orang mengintegrasikan kehidupan pekerjaan mereka dengan peran-peran kehidupan yang lain seperti: keluarga, komitment, dan waktu luang.

Orang memiliki jauh lebih banyak kebebasan dalam penciptaan kehidupan pekerjaan.Tugas perkembangan ini bukan satu yang jelas atau mudah, juga tidak selalu berakhir dengan baik. Namun, paling pasti mempengaruhi kesejahteraan yang lebih luas dari individu, keluarga, dan masyarakat. Menurut pandangan teori konstruksi karier Savickas (Maree, 2008), individu berpotensi menjadi bagian sentral dari dirinya hidup dan menekankan pembangunan makna karir dalam konteks yang unik. Ini menyiratkan bahwa individu memiliki kesempatan untuk mengidentifikasi cara mereka dengan menyesuaikan karir. Fokusnya adalah pada pilihan karir, kemampuan beradaptasi dan berkembang sebagai proses terpadu.Savickas (2005) berpendapat bahwa konstruksi karir tidak hanya menawarkan teori kerangka kerja untuk memahami perilaku kerja, tapi juga memberikan strategi dan metode konseling yang dapat digunakan karena mereka berusaha untuk mencapai penyelesaian sendiri dan membuat sosial kontribusi melalui pekerjaan mereka.

Situasi karir dapat berubah dengan cepat, oleh karena itu konselor harus berusaha berguna bagi klien misalnya menawarkan ruang di mana klien dapat menemukan karakteristik pribadi subjek, dan mengembangkan dan berbagi masa lalu cerita (pengalaman) saat mereka mencoba menavigasi diri serta mengatasi kelemahan masa lalu dan sekarang. Oleh karena itu terus menjadi perhatian, baik di dalam dan di luar psikologi kejuruan, sejauh mana individu dan kelompok memiliki cukup kebebasan dan dukungan dalam penciptaan karier mereka. Olehnya itu, jika dalam (Mappiare, 2017: 6) disebutkan bahwa konseling adalah produsen budaya, dimana dalam bagian sifat klasik layanan 
konseling, konseling developmental memiliki peran dalam mengembangkan masyarakat melalui pengembangan individu-individu dan kelompok kecil. Maka, dalam hal ini implikasi konseling dalam menghadapi tipe konseli yang serupa atau setipe dengan subjek, diharapkan ada upaya bimbingan untuk membentuk unsur-unsur karakter individu baik jangka pendek atau jangka panjang untuk lebih baik atau lebih bermanfaat.

\section{KESIMPULAN}

Definisi diri adalah proses dimana seseorang mampu untuk mendefinisikan dirinya dengan pertanyaan dasar siapa saya. Hal ini adalah bagian awal dari proses pembentukan konsep diri yang nanti berujung pada label identitas diri. Sedangkan definisi situasi adalah proses dimana dalam setiap mengawali tindakan selalu ada tahap pengujian dan pertimbangan dengan memaknai setiap situasi yang dihadapi.

Subjek adalah anak yang memiliki definisi diri positif sebagai pemuda yang memiliki kemampuan "survive" sebagai pemburu kerja. 1) sederhana dan rendah diri, 2) kemandirian, 3) pekerja keras, 4) pemberani, 5) malu jika tidak bekerja, 6) seorang petualang, 7) terampil, dan 8) motivasi yang besar, 9) petarung, 10) Nomaden (pekerjaan tidak tetap), dan 11) kemamapuan penyesuaian diri. Adapun aspek ini dibagi menjadi dua kategori yaitu definisi diri superior yang dilihat berdasarkan aspek dominat atau menonjol yang akan berpengaruh terhadap performa kerjanya, serta bagian kedua yaitu definisi diri inferior sebagai aspek yang resesif yang bersifat pendukung.

Definisi situasi kerja Subjek pada intinya memiliki puncak dari definisi-definisi situasi yang terbentuk, yaitu anggapan tentang pekerjaan yang baik adalah yang bebas. Hal ini kemudian menjadi dasar lahirnya beberapa aspek definisi situasi yang kemudian dikelompokkan menjadi dua bagian yaitu pertama definisi situasi sebagai enabling factor dan definisi situasi sebagai contraining factor. Definisi situasi sebagai enabling factor adalah situasi kerja yang membuat subjek merasa ada faktorfaktor pendukung dan bermanfaat bagi perjalanan kariernya. Adapun aspek itu adalah 1) pekerjaan adalah temapat belajar, 2) pekerjaan adalah temapat aktualisasi diri, 3) pekerjaan adalah wadah evaluasi diri, 4) pekerjaan adalah jalan rejeki.Sedangkan definisi situasi sebagai contraining factor adalah situasi dimana subjek melihat bahwa situasi kerja yang ditemui belum sesuai dengan ekspektasi yang diimpikan disertai dengan ditemukannya factor-faktor penghambat dalam mencapai tujuan dan impiannya. Adapun aspek itu adalah 1) bekerja dibawah tekanan dan 2) dukungan keluarga yang tidak sejalan dengan dirinya.

Oleh karena itu berdasarkan aspek definisi diri dan definisi situasi subjek, tipe konseling yang cocok untuk subjek yang adalah konseling developmental.Hal ini sesuai dengan sifat klasiknya bahwa konseling ini berperan untuk mengambangkan masyarakat melalui pengembangan individu serta sebagai upaya untuk membentuk karakter-karakter individu yang lebih baik atau bermanfaat.

\section{DAFTAR PUSTAKA}


Egloff, Rainer. 2015. Definition of the situation: History of the Concept. International Encyclopedia of the Social \& Behavioral Sciences, 2nd edition, (6) 19-23.

Fromm, E. 2004. Masyarakat Bebas Agresivitas: Bungai ramapi karya Erich Fromm. Semarang: Bina Putera.

Herr, E. L. \& Cramer, S.H. 1984. Career Guidance and Counseling Programs. Englewood Cliffs, N.J. : Prentice-Hall,Inc.

Hamilton,RT\&D.A. Harper.1994. The Entrepreuneur in Theory and Practice. Journal of EconomicStudies, 21(6), 3-16

Mappiare-AT., A. 2013. Tipe-tipe Riset Kualitatif untuk Eksplanasi Sosial Budaya dan Bimbingan Konseling. Penerbit Elang Mas Malang.

Mappiare-AT.,A. 2017. Meramu Model Konseling berbasis Budaya Nusantara : KIPAS (Konseling Intensif Progresif Adaptif Struktur). Malang: UM

Mare, J. 2010.Brief Overview of The Advancement of Postmodern: Approaches to Career Counseling. Journal of Psychology in Africa.20(3), 361-368. USA: University od Pretoria.

Robak, R.W. 2001. Self-Definition in Psychotherapy: Is It Time to Revisit Self- Perception Theory? North American journal of Psychology, 3(3), 529- 534. Mendeley Desktop.

Savickas, M. L. (2005). The Theory And Practice Of Career Construction. Career development and counseling: Putting theory and research to work .42-70. New York, NY: John Wiley.

Super, D. E. 1985. Coming of Age in Middletown: Careers in The Making. American Psychologist, 40 (4). 405-414

Weiner, B. 1986. An Attibutional Theory of Motivation and Emotion. New York : Springe-Verlag. 